\title{
A munkaviszonyok fellazulása
}

„A munka, amely évtizedeken keresztül a termelés talán legmerevebb, legnehezebben mozdítható tényezője volt, az utóbbi két-három évtizedben mozgásba jött.” A cikk azokat a változásokat elemzi, amelyeket az információs technológia idézett elő a munka világában. A távmunka típusainak, gazdasági-társadalmi jelentőségének bemutatása mellett, a cikk sorra veszi a stratégiai rugalmasságot biztosító egyéb foglalkoztatási módszereket.

\section{Szerzői információ:}

Szabó Katalin

egyetemi tanár, fốszerkesztô, 1966 óta dolgozik a Budapesti Közgazdaságtudományi és Államigazgatási Egyetemen, illetve jogelődein - 1988-tól egyetemi tanárként. 1973 óta a Közgazdasági Szemle szerkesztổje, 1986-tól főszerkesztôje. 2001-ben vendégtanár a Purdue Universityn (USA). Az MTA IX. Osztály tanácskozási jogú tagja, kutatási területe: az információgazdaság és a piaci tranzakciók, továbbá a tanulás és felejtés a vállalati szervezetben. 25 tanulmányúton, illetve nemzetközi konferencián vett részt a világ különböző egyetemein. 301 publikációt tett közzé, köztük 12 könyvet. Legfontosabb munkái: Nagyvállalati kihívás (1974), A lágyuló gazdaság (1989), A posztmodern vállalat (2000) - társszerzôvel, a Digitális paradicsom vagy falanszter - A személyes tömegtermelés. (2002) - társszerzővel, és a számos kiadást megért Kommunikácó felsőfokon (2002).

Így hivatkozzon erre a cikkre:

Szabó Katalin. „A munkaviszonyok fellazulása”.

Információs Társadalom III, 1. szám (2003): 75-95.

https://dx.doi.org/10.22503/inftars.III.2003.1.5

A folyóiratban közölt müvek

a Creative Commons Nevezd meg! - Ne add el! - Így add tovább! 4.0

Nemzetközi Licenc feltételeinek megfelelöen használhatók. 
Szabó Katalin

\title{
A munkaviszonyok fellazulása
}

\section{Paradigmaváltás a munka világában az információtechnológiák hatására'}

\author{
Ha minden olyan jó, akkor miért érezzük ilyen rosszul magunkat? \\ A Forbes magazin kérdése
}

Marc Vollenweider néhány éve még partnerként dolgozott a McKinsey indiai (Új-Delhi) részlegénél. Önállósítva magát olyan vállalkozásba fogott, amely igencsak figyelemre méltó. Partnerével (akit az IBM delhi kutatórészlegétôl sikerült átcsábítania) megalapították az Evalueserve-t. A cég különféle irodai munkákat vállal európai és amerikai ügyfelek számára, olcsóbban, jobb és gyorsabb szolgáltatást kínálva, mintha ügyfeleik maguk végeznék el a szóban forgó feladatokat. Vollenweider partnerével, Alok Aggarwallal nagy reményekkel kecsegtető üzleti lehetőséget ragadott meg. Felismerték, hogy az első világbeli társaságok számos olyan dologgal foglalkoznak, amely nélkülözhetetlen ugyan a gördülékeny üzletmenethez, de igen drága, s mégis - valamilyen szempontból - másodlagos az alaptevékenységükhöz képest. Az említett üzleti folyamatok ellátásához semmi másra nincs szükség, mint intelligens, angolul jól beszélő munkavállalókra. Ebben India tényleg bővelkedik. Az sem lényegtelen, hogy az indiaiak minden piacon értékesíthetố képességeiket a fejlett országokban nyújtott bérek töredékéért kínálják. (Back office..., 2001:60)

Az Evalueserve - a Brazíliától Dél-Afrikáig gomba módra szaporodó hasonló vállalkozásokkal egyetemben - olyan szervezet, amely újfajta tér-idó dimenzióba helyezi az ï氵leti folyamatokat.

\section{A tér újraértelmezése a munkafolyamatban}

Az effajta üzleti vállalkozások azért múködhetnek, mert az információtechnológiák a tudás mind nagyobb részét változtatják explicit, kodifikálható, sæabályokba foglalható tudássá, amely könnyen transaferálható. E technológiáknak köszönhetôen a szellemi munka, illetve az intellektuális szolgáltatások „tradeable” jószágként vagy vállalaton belüli transzferként keringenek a világgazdaság csatornáiban, egyaránt átlépve az államok és a kultúrák határait.

\section{A globális iroda}

Az Evalueserve-hez hasonló háttérirodák létesítése a világgazdasági centrumoktól távol esố régiókban ma már egyáltalán nem számít kuriózumnak. A globális iroda múködésérôl érzékletes képet nyújt a Business Week alábbi cikke: 
„Ha hajnali kettő vagy három körül véletlenül betéved a Source 1 Asia manilai irodáiba, azt gondolhatja, hogy kollégisták vizsga elốtti végsố biflázási hajrájába csöppent. Körülbelül 750 - húszas éveinek elején járó - fiatal iszogatja a capuccinóját, és majszolja a szendvicsét. A barlangszerû terem falai lilára, rózsaszínre és citromsárgára vannak mázolva. A fiatalok azonban egyáltalán nem a matematikai alapvizsga miatt mossák egybe az éjt a nappallal. A Chevron Texaco - vásárlóival szembeni - hitelkártya-követeléseinek a behajtásával foglalatoskodnak, és Microsoft-programok gyakorlatlan felhasználóit kalauzolják a szoftverek útvesztőiben... Körülbelül 10000 fillipinó (majdnem mind fốiskolai diplomával) dolgozik ebben az iparágban, a 45 háttérirodai központ (back-office center) valamelyikében. Az irodákban a munka megszakítás nélkül, a nap 24 órájában és heti hét napon át folyik. Az ország alacsony béreinek, nagylelkú adóztatási gyakorlatának és az angolul beszélốk bôséges kínálatának vonzereje olyan társaságokat csábított a Fülöp-szigetekre, mint az American Express (AXPS), az Eastman Kodak (EK), az Intel (INTG), Microsoft (MSFT) és a DellComputer (DELL).” (Balfour, 2003:1)²

A „globális iroda” ötlete már 80 -as évek végén felbukkant. Az úttörő a New York Life Insurance volt. A társaság már 1988-ban Írországba, Castleisland-be telepítette át a háttérirodai munkák egy részét.

„A New Yersey-ben lévố központ a kárigények számítógépes feldolgozását a Zöld Sziget említett falucskájában végezteti. A New York Life Insurance, amely fố múködési terepén, Amerikában nem talált elég gyakorlott embert a számítógépes adatfeldolgozásra, a világ e távoli sarkában jól képzett, fiatal számítógép-szakemberek egész hadára lelt, akik természetesen jóval alacsonyabb bérrel is beérik, mint amerikai kollégáik. A New York Life klienseinek kárigényei számítógépes hálózati összeköttetésen keresztül futnak be az írországi irodába az óceán túlsó partjáról, majd az elintézést nyert akták visszakerülnek a vállalat fôhhadiszállásán lévô számítóközpontba. Az információtechnológia lehetővé teszi, hogy fehérgalléros munkások olyan irodai feladatokat lássanak el, amelyek tőlük sok ezer kilométerre fogalmazódtak meg. (Szabó, 1995:19)

Az irodai munka globalizálásának említett három esete a világ három távoli egymástól sok ezer kilométerre lévố - sarkából és különbözô időpontokból származik. Van azonban néhány közös vonásuk: 1. Egyik sem jöhetett volna létre az információtechnológiák ${ }^{3}$ és a földrészeket behálózó Internet nélkül. 2. Mindhárom példában szembeötlő a szellemi munkafolyamatok decentralizálása és globalizálása. 3. Mindhárom eset korábban elképzelhetetlen térben és idóben is értelmezhetố rugalmasságot követel a munkavállalótól és a cégtôl egyaránt. 4. A globális irodákat múködtető, vagy a tőlük szolgáltatásokat vásárló cégek valamennyi esetben jelentős költségmegtakaritást könyvelhetnek el, a fejlett országokban zajló hasonló folyamatok költségeivel összevetve e megoldást.

A elő́bb említett közös vonások egyáltalán nem függetlenek egymástól. Az információtechnológiák és a világháló teszi lehetővé az első világbeli technológia összeházasítását a harmadik világbeli bérekkel, és e „házasság” eredménye egészen egyedülálló ver- 
senyképesség-növekedés, mind a kezdeményezô cégeknél, mind az érintett országokban. A globális iroda nyilvánvalóan elképzelhetetlen a: információtovábbitás költségeinek, aะa: a tran:akciós költségeknek a radikális csökkenése nélkül.

Manapság már 30.000 német márka elég ahhoz, hogy akár 100 kilométerre a legközelebbi falutól - az érintetlen ôserdôbôl is - belépjen valaki a világpiacra. Ehhez nincs is másra szüksége, mint egy multimédiás munkahelyre, energiaforrásra és múhold-összeköttetésre. A Nordstrom vagy a Compaq foghíjas stábját éppúgy a fejlődő országok távmunkásaival tölti fel, mint az IBM, a Time Warner vagy a Sealand Services nevú hajózási óriás. A nagy német cégek Indiában végeztetik utazási költségeik elszámolását, vevőszolgálatukat pedig a Bahamákra telepítették ki. Vannak nagy autógyárak, amelyek az egész világot átfogó teameket múködtetnek a CAD-modellek felhasználására. (Rademacher, 2003) Már 1996-ban(!) több mint 100, a Fortune 500as klubjába tartozó cég vásárolt szoftverszolgáltatásokat Indiából. Az indiai a programozók ugyanis az amerikai bérráta kevesebb, mint negyedéért vállalták a munkát.(The China Syndrome, 1996:31)

Az irodai munka a 80-as évektôl kezdődő kitelepítése a 21. század küszöbére érkezve felerôsödött. A fejlett országok vállalatai évrốl évre egyre növekvố mértékben helyezik át az ilyenfajta munkákat Indiába, Írországba vagy éppen Brazíliába. Ahogyan a 70-es 80-as években a világvállalatok gyártókapacitásaikat a harmadik világ számos országába szórták szét, úgy telepitik most ki a multik irodáikat lényegében minden erre alkalmas földrajzi régióba.

A legszárnyalóbb elốrejelzésekkel e trendet illetốen India vonatkozásában Michael Dertouzos, a MIT számítástechnikai laboratóriumának igazgatója állt elő. Dertouzos szerint Indiának kb. 50 millió angolul jól beszélő polgára van, akik - a tér és idő korlátainak lebontását kihasználva - egyenként 20 ezer dollárt tudnának keresni évente, azaz összesen 1 billió dollárt, kétszer annyit, mint India jelenlegi GDP-je. (Back office..., 2001:60) Nem kevésbé merész a MIT egy tanulmányának a fejlett ipari országokra (a G7-csoportosulásrra) vonatkozó prognózisa sem. A tanulmány szerint 2010-re a vezető ipari országok (G7) összes munkahelyének elvben 80\%-a (!) kihelyezhetô lesz. (Rademacher, 2003)

Az irodák kihelyezését - akárcsak annakidején a termelés kitelepítését - a fejlődő, illetve a feltörekvő országok alacsony bérszintje, az általuk nyújtott adóelőnyök, illetve az ebből fakadó megtakarítások mozgatják.

Egy román $\mathrm{PhD}$-fokozattal rendelkező matematikus körülbelül az egytizedét kapja annak, amihez hasonló képzettségú amerikai kollégája jut. Az átlagos ír programozó 17 és 21 ezer dollár között keres, míg ugyanezek a számok az amerikai programozó esetében majd kétszer nagyobbak (33.000 - 51.000 dollár) Ráadásul a fejlődő országbeli távmunkások esetében meglehetôsen kevés rejtett költséggel kell számolni. A legtöbb esetben az utazási költségek, a távolsági beszélgetések és a múholdas kapcsolat 9000 dollár/hónapra rúgó költsége is benne foglaltatik az óránkénti és személyenként meghatározott díjban, amelyet a programozókat igénybe vevő cégnek felszámolnak. A 
háttérirodákat létesítô világcégek kezére játszik a fejlődô országok (és a feltörekvô országok) munkahelyek iránti csillapíthatatlan éhsége is. Írország például arra tett ígéretet, hogy a 10 százalékos társasági adót 2010-ig nem emeli. (Scheier, 1995:E1)

Az imént tárgyalt háttérirodai munkák csak az egyik változatát képezik egy sokkal általánosabb jelenségkörnek: a tármunkának.

\section{A távmunka}

Távmunkán azt értik, hogy az ember munkaadójától vagy megrendelôjétől, ügyfelétól egy bizonyos távolságban dolgozik, akár otthon, akár útközben, akár pedig egy helyi tármunka-központban. Ebben az új üzleti környezetben a munkavállaló (vagy az önfoglalkoztató) szinte bárhol elvégezheti a rábízott feladatot, minden idốbeli korlát nélkül, amíg csak hozzáfér a telefonvonalhoz, a faxhoz vagy a számítógéphez, amely összekapcsolja ốt a munkaadójával, vevôjével vagy kliensével.

Többféle teledolgozó létezik: 1. ipari távmunkás, 2. „telehivatalnok” 3. távszakértő és telemenedzser. Az ipari teledolgozó kizárólagosan otthoni munkát végez, ez a foglalkoztatási forma különösen az önfoglalkoztató vidéki munkavállalókra jellemzô. ${ }^{5}$ A legtöbb ilyen munkás nő, és gyakran alulfizetett. A második csoportba, az alacsonyabban kvalifikált hivatali teledolgozók körébe sorolhatjuk programozókat és vevôszolgálati alkalmazottakat is. A harmadik csoport helyezkedik el legmagasabban a rang-

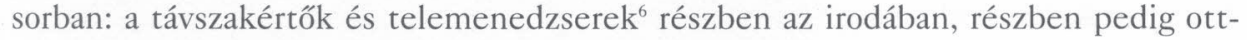
hon végzik a munkájukat. A második és a harmadik kategória javarészt a szabadúszó teledolgozókat tartalmazza, az ő esetükben van a legnagyobb lehetôség annak kihasználására, hogy helyileg bárhol lehetnek, beleértve a legtávolabbi vidékeket, legkiesőbb falvakat is. Erre a kékgalléros távmunkásoknak jóval kevésbé van lehetôségük.

A távmunka paradox módon mégis jóval lassabban terjedt el a városoktól távol eső vidékeken, mint a városi körzetekben. A Rural Development Commision egyesült királyságbeli vizsgálata szerint a távmunka fóként városi vagy külvárosi ingázóknak kedvez.(Teleworking and Rural..., 1996) A távmunka jelentősége először olyan területeken mutatkozott meg (például Kaliforniában az 1980-as években), ahol megoldásokat kerestek a városok környékérôl a városi központi irodákba ingázók problémáira. (Bertin \& O’Neill, 1996). A távmunkával szemben a legerôsebb kezdeti ellenállás azoknál a vállalatoknál volt tapasztalható, amelyek ódzkodtak attól, hogy távoli, ismeretlen csoportokat vonjanak be munkafolyamataikba. A szokatlan megoldásokkal szembeni kezdeti ellenállás azonban hamar felmorzsolódott, és a távmunka lendületesen terjed. A cégek gyorsan belátták, hogy az irodai munkák gyakorlatilag ugyanolyan színvonalon elvégezhetốk otthon vagy az ember autójában, mint a cégközpontban az ISDN (videokonferencia, gyors fájltovábbítás), az Internet, a telefon és a fax használata révén. Az információtechnológiákhoz legközvetlenebbül kapcsolódó távmunka „tortájának” öt szelete - tudásigényességüket, értéküket tekintve növekvő rangsorban - a következő:

- adathalmaz feldolgozása, belépés az adathalmazba és az adathalmaz konverziója (például orvosi szövegek konvertálása egyik jelformából egy másik jelformába); 
- szabálykészlet alkalmazása, amikor a távmunkás a megrendelő által felállított szabályok alapján hoz döntést (például eldönti, hogy az adott repülési szabályok mellett beültethetô-e egy utas az elsô osztályú utastérbe, vagy sem);

- problémamegoldás, amelynek esetében a távmunkás döntési, mérlegelési szabadsága nagyobb az előbbinél (eldöntheti például, hogy kell-e fizetnie a biztosítónak egy adott biztosítási ügyben;

- közvetlen interakció a fogyasztóval, amelyben a távmunkás többféle, bonyolult tranzakciót folytat a cég ügyfeleivel, illetve a vevőivel (például: begyújti a hátralékfizetéseket, megszünteti a komputerben keletkezô váratlan akadályokat stb.);

- tudásszolgáltatás, szakértés - ez a munka szakértőt igényel (adatbázisok segítségét is igénybe véve), például: a távmunkás előrejelzést készít arról, hogy a hitelkártya tulajdonosának a magatartása milyen irányban változik akkor, ha a hitelkamatok csökkennek (Back office..., 2001:60). Az információtechnológia lehetôvé teszi az eredetileg az ún. „non tradable” kategóriába tartozó szakértối szolgáltatások exportját is. Az orvosi tanácsadás vagy oktatás ma nagy távolságokra is eladható a telekommunikációs hálózatokon keresztül (The China Syndrome, 1996:31)

A szervezeti-tulajdonjogi megoldásokat tekintve az IT-alapú távmunka két fó csoportja különböztethető meg: a cégek tevékenységébe közvetlenül integrált munka (captive work) és az önfoglalkoztatók vagy független sæeræödők által végæett független távmunka. A tudásszolgáltatás-szakértés többnyire a nagyvállalattól független cégekhez kötôdik, míg az adathalmazok kezelése gyakoribb a cégek szervezetébe integrált háttérirodákban. Általánosságban elmondhatjuk, hogy minél magasabb rendü munkáról van szó, annál valószínúbb, hogy kisebb független szerzödő cégek vagy önfoglalkoztatók végzik. A két forma között azonban nincs éles választóvonal, s a szakirodalomban sem mindig különböztetik meg óket egymástól. Egy-egy egyén karrierjében is sokszor átmegy az egyik fajta munka a másikba. A cégek azon munkatársai például, akik sikeresen igyekeznek függetlenedni a nagyvállalati kötöttségektől, gyakran önfoglalkoztatóként, kívülrốl kapcsolódnak a vállalathoz.

Milyen előnyökkel jár a távmunka a hagyományos irodai tevékenységhez képest? A távmunkából a legnagyobb hasznot természetesen a vállalatok húzzák, mert

- alacsonyan tarthatják rezsiköltségeiket (Sokkal kevesebb utazási költséggel kell számolniuk például, mint e nélkül a megoldás nélkül.);

- tetszốlegesen növelhetik alkalmazottaik számát, anélkül, hogy érdemleges tőkebefektetésre kényszerülnének;

- „nyitva tartásukat” is szinte korlátok nélkül, rugalmasan alakithatják, ezáltal növelve klienseik kényelmét.

De előnyt húznak a távmunkából a munkavállalók is, mert

- a távmunkásként foglalkoztatott munkavállalók kisebb stressænek vannak kitéve, mint a hagyományos keretek között dolgozó irodai alkalmazottak (Ez főként 
annak köszönhetô, hogy a távmunkások jobban összeegyeztethetik a munkájukat családi és egyéb kötelezettségeikkel, mint a hagyományos keretek között foglalkoztatottak).

- A munkába járás kiküszöbölésével vagy radikális csökkentésével kevesebb a holtidố, ami szintén korlátozza a stresszhelyzeteket.

Az előnyök nemcsak a közvetlenül érintettek szintjén, hanem össztársadalmi szinten is jelentkeznek, mert

- a távmunkások alkalmazásának köszönhetô kevesebb utazás kisebb városi, illetve országúti forgalmat jelent, ezáltal kevésbé terheli a környezetet,

- s a városokból is kisebb hasznos területet hasitanak ki az autóutak és az irodaházak.

Természetesen a távmunkának nemcsak elônyös oldalai vannak. A munkáltató, vagy az effajta szolgáltatatást igénybe vevő szempontjából hátrány, hogy

- bár a távmunka jóval költségkímélőbb, mint a hagyományos, és messze kisebb toborzási, biztosítási költségekkel és vállalati juttatásokkal jár, mint ez utóbbi, mégis jelentkeznek „rejtett költségek”. A rejtett költségek részben a távmunkások alkalmazásával szükségképpen növekvő a monitoringgal függnek össze, azzal, hogy a távmunka bonyolultabbá (s ezáltal költségesebbé) teszi a vállalat kormányzását (Graham, 1995; Smith, 1994; Thomas, 1994) ;

- konfliktusok keletkeznek a hagyományos és tármunkások között, amelyek feloldása szintén költségekkel jár. A konfliktusok elsősorban a bérek, illetve juttatások közötti aránytalanságokra és a munkafeltételek eltérésére vezethetők vissza;

- bizonyos feladatok elvégzésekor - különösen gyorsan változó projektek esetében - nélkülözhetetlen a dolgozók közötti ,face to face" kapcsolat, s ennek hiánya hatékonyságcsökkentố hatású. (Scheier, 1995)

A munkavállaló szempontjából hátrány, hogy

- a távmunkások számára biztosított jogok és juttatások általában kisebbek, mint az állandóan jelen levố dolgozóké, hisz éppen ez teszi vonzóvá ezt a megoldást a vállalatok számára;

- ezen túlmenően sæámos költséget, amelyet korábban a vállalat viselt (fútés, világítás stb.) a táomunkásnak kell állnia;

- távmunkásként meglehetôsen nehéz a beilles»kedés, a dolgozó gyakran úgy érzi, hogy sehová sem tartozik;

- az állandó rendelkezésre állás (amelyet többnyire elvárnak az ilyen formában dolgozóktól) is stresszel jár, nemcsak a dugóban ácsorgás a munkahelyre menet.

A társadalom szempontjából az lehet hátrányos, hogy

- a kevesebb vállalati törődésben részesülő dolgozók, azaz a tármunkások, jobban megterhelhetik a költségvetést késôbb, ha már öregek vagy betegek lesznek. 


\section{A távmunka táguló lehetöségei: A termelés dematerializálódása}

A távmunka egyáltalán nem szorítkozik a szűken vett vállalati adminisztráció világára, alkalmazási lehetőségeit messzemenően kibôvíti a termelési folyamatok dematerializálódása. A javak mindinkább „információtelítetté” válnak. Termelésükben mind nagyobb szerepet kap a tudás. A tudásipar tehát messze túlterjed a számítógépes hardver és szoftveripar, a távközlési szolgáltatások, vagy az ún. tartalomszolgáltatók körén, azaz szélesebb kört ölel fel, mint amekkorát szokványosan tudásiparként tartunk számon, Manapság már majdnem minden ipar többé-kevésbé tudásipar. Némi túlzással azt is mondhatnánk, hogy a 21. század küszöbén a nyersanyagok is többé-kevésbé információ alapú termékek, amelyek magas hozzáadott értéket tartalmaznak. Példa erre az olaj, de számos más nyersanyag esetében is hasonló a helyzet.

„A tudás, és nem az olaj válik a legfő́bb nyersanyaggá az olajüzletben” - fogalmazta meg Rauch a fejlődés lényegét e hagyományos kitermelőipar informatizálásáról szóló cikkében. Az elmúlt egy-két évtizedben, az olajkitermelésben olyan mélyreható változások következtek be, hogy ma már nyugodtan állíthatjuk: nem az olaj kiszivattyúzása a kulcstevékenység ebben az iparágban. A szivattyúk múködtetőit háttérbe szorították a szoftverfejlesztốk és a komputerek ${ }^{7}$. A szoftverfejlesztốk munkája azonban kihelyezhetô, akár a vállalat otthon ülő alkalmazottaihoz, vagy egy - a világ másik sarkában található - szoftvercéghez. (V. ö: Rauch, 2001:35).

Ugyanezt állapíthatjuk meg azonban jó néhány korábban egyértelmúen anyagi jellegú termék előállításáról - például az autóéról. Az utóbbi két-három évtizedben e „kézzelfoghatóan” materiális jellegú iparban is meghatározóvá vált az informatika. Az autóba épített elektronika súlya a hozzáadott értékben éppoly látványosan növekszik, mint a vállalatirányításban, a beszállítókkal fenntartott kapcsolatban, vagy a termelési folyamat logisztikai hátterének biztosításában alkalmazott szoftverek jelentôségében. Az Automotive Industries címú újság , 2000 októberében közölt becslése szerint, az autó teljes értékének ma már 22 százalékát teszi ki az elektronika, és ez az arány 2010-re 40 százalékra növekedhet. (Delphi Brings..., 2000)

A mai technológiák mellett a foglalkoztatottak többsége egyáltalán nem érintkezik a fizikai folyamatokkal. A munkaerô csökkenő hányada kapcsolódik közvetlenül a materiális folyamatokhoz, nagyobb része a termelés szellemi elókészítésében, a termelést körülölelő szolgáltatásokban és a vevókkel fenntartott kapcsolatban hasznosul. Eะ a fajta munka azonban már kihelyezhetô, sokkal inkább alkalmas arra, hogy a vállalathoz csak lazán kapcsolódó távmunkások végezzék, ellentétben a futószalagok mellett végzett hagyományos munkafajtákkal. Annak idején az ipari társadalom zajos-búzös nagyüzemekben koncentrálta a munkásokat, kiszakította ôket az otthonukból, élesen elválasztotta a szabadidôt a munkaidôtốl. Most éppen ennek a történelmi folyamatnak a fordítottja zajlik:

„Bár nagyon kevés konkrét szám áll rendelkezésünkre, de a Cyber Dialogue adatai szerint 1990-ben mintegy 4 millió távmunkás dolgozott az otthonában, 1999-ben pedig már 19,9 millió. A számuk egy évtized alatt megötszöröződött. És ez a szám 
még nem tartalmazza azt a mintegy 21,4 millió önfoglalkoztató távmunkást, akik az Internetet használják a klienseikkel folytatott ügyletekben (Mokyr, 2001:10).

Egyelőre persze még túlsúlyban van a hagyományos foglalkoztatás, de ebbôl nem szabad messzemenő következtetéseket levonni. Ha a távmunka jelentőségét helyesen akarjuk megítélni a régi iparágakban, akkor inkább a trendekre ${ }^{8}$ kell figyelni, mint a jelenlegi adatokra.

A távmunka különbözô formáinak terjedése csak egyik példája azoknak a kardinális változásoknak, amelyek szerte a világon tapasztalhatók a foglalkoztatási viszonyokban. A munka, amely évtizedeken keresztül a termelés talán legmerevebb, legnehezebben mozditható tényezóje volt, az utóbbi két-három évtizedben mozgásba jött. A jelek arra utalnak, hogy a munka is éppoly mobillá, változtathatóvá válik, mint maga az informatizált termelési folyamat és az azt meghatározó információtechnológia. „Munka bármikor és bárhol - ez az új paradigma. A kocsidban, az otthonodban, az irodádban, a kliensed irodájában. Munka egyedül, párban, teamben! Munka a reális térben és a cybertérben! Ez a munka masszív dezaggregációját jelenti, kitörve a falakon túlra és a hagyományos irodák kereteiból egyaránt. ${ }^{9}$ (My Workplace, 2003:1)

A mozgékonyság, rugalmasság azonban nemcsak a földrajzi térben értelmezhetô, hanem időben is. A tág értelemben vett információtechnológiák lehetőséget adnak arra, hogy az idốt és a helyet ne adottságként, tevékenységünk üres kereteként kezeljük, hanem változtatható paraméterként határozzuk meg újra és újra. E technológiák elsődleges következménye az idő süritése és kitágitása. Miközben a virtuális kommunikáció gondoskodik az információ gyorsabb áramlásáról, elképesztő időmennyiséget sưrítve a percekbe és a másodpercekbe, azt is lehetôvé teszi az embereknek, hogy a dolgokat a saját ütemükben és idejükben végezzék el, azaz egyben ki is tágítja számukra az idôt. Míg a klasszikus tömegtermelésben a vállalati folyamatok a munkavállalóktól független ütemben, adott idóben és többnyire adott (de legalábbis jól körülhatárolható) térben zajlottak, addig a 21. század vállalatai $a$ z idôt és a teret többféle módon kombinálhatják. Ez vonatkozik a foglalkoztatás időtartamára, idôhorizontjára is.

\section{A munka időhorizontiának radikális változásai: A feltételesen foglalkoztatottak}

A klasszikus, tömegtermelésre - különösen annak ún. fordista szakaszában - viszonylag stabil, hosszú idöre rögzitett, néha élethossziglan fenntartott munkaviszonyok a jellemzőek. A termelés nagyszámú, speciálisan egy-egy adott gépsorra, vagy munkafolyamatra kiképzett munkavállalót igényel. A munka hatékonyságában nagy szerepe van a gyakorlatnak, a tapasztalatnak. A specializált munkaerő kétoldalúan is a vállalathoz kötött: sem a munkavállalónak nem előnyös ugyanis, hogy kezdőként mindent újra kelljen tanulnia egy másik vállalatnál, egy másik speciális munkafolyamatban, sem a vállalatnak nem érdeke, hogy cserélgesse a munkavállalókat, hisz a csere következtében elvesznének a tapas:talatok, a munkavállaló kiképzésének a költségei. A stabilitás sokszor több generáción keresztül is átnyúlik, gyakran ugyanannak a családnak harmadik-negyedik generációja dolgozik egy-egy adott gyárban vagy bányában. 
A merev, nehezen változtatható termelési folyamatokban mindkét oldalról megéri a tartós foglalkoztatás. A hosszú távra szóló (vagy határozatlan idejű) munkaszerződések tulajdonképpen csak ezt szentesítik. A szerződések azonban természetesen sohasem lehetnek teljesen zártak, hiszen bizonyos eshetôségeket vagy visszaélési lehetôségeket a szerzôdés megkötésekor nem látni elôre. Ezért a hosszú távú munkaviszonyban a munkáltatónak és a munkavállalónak egyaránt bizalmat kell elólegeznie. A munkaerő speciális szaktudása és képességei a tôkespecifikusság (asset specificity) és visszafordíthatatlanság egy jellegzetes fajtáját képviselik. Minél nagyobb a fenti két változó súlya, annál nagyobb az állandó munkaerő alkalmazásának valószínúsége. (Foote \& Folta, 2003)

Az informatizálódó gazdaságban azonban minden másképpen van. E gazdaságra nem a hosszú távú beruházási elkötelezettség a jellemæó, hanem a gyors váltás. Az információtechnológián nyugvó termelés ebből következően nem tür semmiféle tartós elkötelezốdést, vagy legalábbis radikálisan lecsökkenti ennek terrénumát. Egy ilyen „környezetben senki sem tudja valójában, hogy mit akar a következő vevő, ennélfogva azt sem tudják, hogy mit fog produkálni legközelebb a társaság. Senki sem tudja, hogy a piaci lehetôségek mely ablakai tárulnak fel, és ezért senki sem alakithat ki hosszú távú víziót meghatározott termékekról, hogy kiszolgálja azok piacát. De mindenki tudja, hogy a következố vevő akarni fog valamit, és hogy meg fog nyílni egy piaci lehetôség” (Pine et al., 1993:119)

Logikailag is belátható, hogy az informatizált, az egyes fogyasztó igényeihez alkalmazkodó rugalmas, termelés ${ }^{10}$ nem férhet össze a hagyományos 8 órás, állandó foglalkozatással, még kevésbé az élethossziglan tartó munkaviszonnyal. Az életfogytiglan tartó munkaviszonynak és az évtizedekre kialkudott stabil munkafeltételeknek - úgy tûnik - lassan lejár az idejük. Becslések szerint az 1980-as évek közepe óta az Egyesült Államokban körülbelül minden ötödik új állás a feltételes vagy ideiglenes munkalehetőségek valamilyen formája (Cappelli et al., 1997).

\section{A feltételes foglalko:tatás fajtái}

A fejlett gazdaságokban élők egyre nagyobb hányada úgynevezett feltételes foglalkoztatott (contingent workers), akit alkalmanként, részmunkaidőben, nem egész éven keresztül vesznek igénybe a munkáltatók. „Tágabb értelemben, minden foglalkoztatás feltételekhez kötött. Szúkebb értelemben azonban azokat a munkavállalási formákat tekintik feltételes munkának (contingent work), amelyeknél a foglalkoztatás bizonytalan és nem biætonságos." (Wiens-Tuers, 2001:46) Az amerikai Bureau of Labor Statistics (munkaügyi statisztikai hivatal) 1989-ban megfogalmazott meghatározása szerint: feltételes munka (contingent work) az a munkavégzés, amelyben az egyénnek sem explicit, sem implicit szerződése nincs hosszú távú foglalkoztatásra. Feltételes munkások tehát azok az egyének, akiknek a munkája ideiglenes és nem várható, hogy folytatása lesz (Hipple, 2001:4). (Kiemelés tőlem - Sz. K.) ${ }^{11} \mathrm{Az}$ alternatív vagy feltételes foglalkozatási formákban dolgozó munkavállalók a következő csoportokba sorolhatók: 
- Önfoglalkoztatók Az önfoglalkoztatók, akiket sokszor "független szerződôként” aposztrofálnak a különféle felmérésekben és csoportosításokban, önálló szerződő félként, tanácsadóként, szabadúszóként kapcsolódnak a vállalatokhoz.

- Szerzódó vállalatok által biztositott alkalmi dolgozók (workers provided by contract firms) Ezek a személyek a szerződő vállalat kötelékében dolgoznak, valójában azonban a szerződő vállalat partnerénél látnak el alkalmi munkafeladatokat. A szóban forgó foglalkoztatottak a nekik munkát adó vállalat (rendszerint csupán egyetlen) megrendelője részére végeznek munkát, magánál a megrendelőnél. Ebbe a kategóriába tartoznak a „kiszerzôdéssel” (contracting out) dolgozók is. Vannak vállalatok, amelyek éppen arra szakosodnak, hogy - szerzôdéses formában - más cégek számára biztosítsák a dolgozókat vagy szolgáltatásaikat (Hipple, 2001:25-27).

- Kölcsönzött munkaerö (temporary help agency workers) A kölcsönmunkások a munkaeró-kölcsönzőkkel állnak jogviszonyban, s fizetést is tőlük kapnak. A munkaerő-kölcsönzôk által foglalkoztatottak abban különböznek a szerződő vállalatok által biztosított alkalmi dolgozóktól, hogy nem egy meghatározott megrendeló cégnél szorgoskodnak, hanem bárkinél, aki kikölcsönzi ôket. Ideiglenes munkájukat mindig annál a vállalatnál végzik, ahová a munkaközvetítő cég küldi őket.

Bár egy maroknyi úttörô már a 20-as években is próbálkozott munkaerô-kölcsönzéssel, az iparág csak a második világháború után kelt életre, és a 70-es évektôl kezdett igazán fejlődni. Az ideiglenes munkaerôt közvetítô cégek a 20. század harmadik harmadában iparággá szerveződtek, mégpedig olyan ígéretes iparággá, amely egyre dinamikusabban fejlődik. A Manpower vagy a Kelly Services nevú globálisan tevékenykedő munkaerő-kölcsönzốk és olyan új európai versenytársaik, mint a Randstad vagy az Adecco mindenütt jelen vannak, nemcsak a nagy üzleti centrumokban, hanem a kieső területeken is. (Theodore \& Peck, 2002:463) Az alkalmi kisegítóket kínáló cégek szerződéses alapon kínálnak alkalmi munkát (alkalmi munkásokat) más cégeknek. Ez a munkaerő-kölcsönzô iparág legfóbb jellemzője (Segal, 1996:526).

- „Hĩúsra házhoz megyek” munkások (on-call workers) A „hívásra házhoz megyek” munkások azok a vállalathoz lazábban kapcsolódó személyek, akiket csak akkor hívnak be dolgozni, ha éppen szükség van rájuk. Ezeket a magyar szóhasználatban idénymunkásoknak vagy beugró munkaerönek is nevezik. Az idénymunkás kifejezés ma már kevésbé találó, hisz a csúcsidôszakok, amikor az on-call workerek csatasorba állnak, egyáltalán nem csak idényhez kapcsolódnak. A felgyorsult világban a helyzet óráról órára is változhat, és e dolgozókat ennek megfelelően meglehetôsen hektikusan hívják be.

- Részidös foglalkoztatottak. A feltételesen foglalkoztatottak speciális csoportját képezik a részidôs foglalkoztatottak (fóként diákok, családanyák), akik rövidebb, 4 vagy 6 órás munkát vállalnak, esetleg csak a hét bizonyos napjain dolgoznak. Óket elvben akár hosszabb távon is lehetne foglalkoztatni, e munkavállalói csoportok jellege (diákok, családanyák) azonban magában hordja az idôbeli lehatároltságot és a munkahelyhez való laza kötődést. Sok ilyen részidôst alkalmaznak például az ügyfélszolgálati központokban. 
Az ideiglenesen foglalkoztatottak, illetve az atipikus munkavállalók között vannak olyanok, akik maguk választják ezt a foglalkoztatási formát, és vannak olyanok is (az elóbbieknél jóval nagyobb számban), akik kényszerbốl dolgoznak ilyen keretek között. A többség rosszul fizetett akadnak olyanok is, akiket jól megfizetnek.

KLA Instruments nevú amerikai cég például külön embert alkalmaz arra, hogy munkavállalókat toborozzon olyan alkalmilag munkát vállaló szakemberek körében, akik a saját elhatározásuk alapján akarnak feltételesen foglalkoztatottak maradni. Nincs nagy kedvük csatlakozni egy vállalathoz. Inkább szeretnek besétálni egy céghez, elvégezni azt, amire vállalkoztak, azután továbbállni.(Lynn:1995)

A fent említettek igazi „nomád munkavállalók”, akik nem is tudnának egy helyben megülni. Ám Chris Tilly, a Massachusetts-Lowell egyetem közgazdásza szerint, a részmunkaidőben foglalkoztatottak 1970 óta bekövetkezett növekedésében a növekmény kétharmada menedzseri döntések következménye, s nem a munkaerô saját elhatározására vezethetô vissza (Harrison, 1997:39).

\section{A feltételes munka és a rendszerböl fakadó bizonytalanság}

Az előbbiekből is kitűnik, hogy a „nem standard”, „atipikus”, „feltételes” munka fogalma zavarba ejtôen sokrétû, s e terminológia nagyon különbözô foglalkoztatási elrendezéseket, szerződéstípusokat vesz egy kalap alá. Van azonban e munkavállalóknak két közös vonása: a foglalkoztatás idóleges, bizonytalan jellege és a laza kapcsolódás ahhoz a vállalathoz, amelynek a munkafolyamataiba betagolódnak. Ez a forma természetesen folyamatosan megkérdôjelezi a szóban forgó munkaerô státuszát. A szék, amelyen ülnek, állandóan inog, munkájuk, šolgáltatásuk folyamatosan a verseny kontextusában van helyezve. Ez még így önmagában nem lenne új, hisz a piacgazdaság velejárója a termelési és munkafeltételek folyamatos átalakulása. Az állásbizonytalanság és a munkanélküliség alapvető szerkezeti ismertetőjegyei ennek a gazdasági rendszernek. Manapság csak a bizonytalanság foka, mértéke szokatlan, s igazából csak a 20. század középső harmadához képest jelent ez újdonságot.

A Nagy Válság, illetve második világháború után a keynesi ihletésű gazdaságpolitikák alapján hosszú ideig „hatályon kívül” helyezték a rendszer eredendô bizonytalanságát. A stabilitást azt tette lehetôvé, hogy a fejlett gazdaságokban a stabil oligopolisztikus struktúrák, ennek következtében a viszonylag lanyhább verseny volt jellemzô. Ehhez logikusan kapcsolódott a nagyvállalatok és az állam érdekközösségét kifejezô állami intervenció magas foka, a belsổ piacok fejlesztésére való összpontosítás, a munkaszerződéssel és társadalmi megállapodásokkal erôsen szabályozott munkaviszonyok és szociális biztonság nemzetállami kereteken belül. E modell azonban a 70es évektốl kezdve a válság jeleit mutatta Minél kötöttebbek és intézményesítettebbek lettek ugyanis a munkaviszonyok, annál világosabbá vált, hogy ez is korlátja a tőkehasznosításnak. A nyilvánvaló problémák csak erősödtek akkor, amikor a taylori munkaszervezetben rejlő termelési játéktér - az egész gazdaságot átfogó informatizálással - kezdett beszúkülni. ${ }^{12}$ 
A 70-es évek válsága után az információtechnológia vette át a vezetô szerepet a gazdaságban. Ez a 90-es években tartós prosperitást hozott, de a prosperitás ára a növekvố bizonytalanság volt. A bizonytalanság a gazdaságban természetesen mindig fennállt, de a gazdaság informatizálásával vált valóban nehezen kezelhetố problémává. A viszonylag lassan változó társadalmakban ugyanis oldani lehetett a bizonytalanságot, kiismerni az ismeretlen tényezôket, volt lehetôség az alkalmazkodásra. Az információtechnológiákkal azonban a gazdaság olyan sebességre kapcsolt, amellyel szinte lehetetlen az aktoroknak lépést tartaniuk. Ha nem tudjuk, mire készüljünk, akkor mindenre fel kell készülnünk. A helyzetból kiutat tehát csak a stratégiai rugalmasság jelent.

\section{A munkaviszony mint portfólió-beruházás: a feltételes munkaerö alkalmaæásának a hasæna}

E rugalmasságnak köszönhetốen a humán tốkeberuházások a vállalatban egyre inkább a portfólió beruházások jegyeit öltik magukra. (Foote \& Folta, 2003) A termelő beruházásokat - bennük a munkaerôvel kapcsolatosakat - korábban éppen az különböztette meg a pénzügyi befektetésektől, hogy míg a pénzügyi befektetések viszszafordithatók voltak és alacsony tranzakciós költségekkel jártak, addig a termelő beruházások hosszú távú, vissæafordithatatlan elkötelezettséget jelentettek és igen magas tranæakciós költségek társultak hozzájuk. Ez utóbbi vonások stabilitást adtak a termelésnek, ami egyben a foglalkoztatás stabilitását is jelentette. Manapság ezzel szemben a termelési és foglalkoztatási döntések pedig a pénzügyi tranzakcióknál megszokott választáshoz kezdenek hasonlítani. Az információs gazdaságban a termelố vállalatok legfóbb feladata ezért az eredetileg vissza nem fordítható humántôke-beruházásból visszafordítható beruházást csinálni, a magas tranzakciós költségeket pedig alacsony tranzakciós költségekké varázsolni.

„...számos cég azzal válaszol az ilyen kihívásokra, hogy a bizonytalanságból eredő vállalkozói kockázatok nagy részét megpróbálja a munkavállalókra hárítani. Gyakori, gyors válaszként adott szokásos megoldás ilyenkor a vállalati méret csökkentése, a „karcsú az, ami gép” (“lean, mean machine”) jelszó jegyében. A munkapiac merevsége és a munkahely implicit biztonsága hamar megszúnik, amint a piaci erốk a rugalmasabb munkapiaci formák felé fordulnak. Alacsonyabb költségek és nagyobb rugalmasság elérésére az üzleti világ gyakran alkalmaz részmunkaidős dolgozókat és nemszabványos munkavállalási formákat. A strukturális változások dolgozókat érintô legfőbb következménye a hosszan fennálló, biztonságos munkahelyek számának zsugorodása. (Wiens-Tuers, 2001:45)

A cégeknek a munkaerô-felvételi döntéseknél jó elôre meg kell tervezniük a késő́bbi elbocsátásokat is. A munkaerôvel kapcsolatos elköteleződést a cégek többféle módon is igyekeznek szúkíteni:

A legkézenfekvőbb a feltételes, nem állandó munkaerő alkalmazása. Ez a cégek számára semmiféle elköteleződést nem jelent. A feltételes munkaerô egy része nem az ôt igénybe vevô céghez kötốdik, hanem egy harmadik félhez: a munkaerô-kölcsönzôhöz vagy munkaközvetítő brókerhez. 
„A foglalkoztatás a munkaadó és a munkavállaló közötti kétoldalú viszonyból olyan jelenséggé fejlődött, amit közvetített (brokered) háromoldalú munkaerố-ellátásnak nevezünk az üzleti szervezet, a munkavállaló és egy harmadik fél a munkaközvetítő (employment broker) között." (Saveri, 1995:94)

A tulajdonképpeni munkaadó számára így nincs végkielégítés, betanítás, munkaügyi per és sorolhatnánk még tovább. Ideiglenes - például kölcsönzött vagy szerződô cégnél foglalkoztatott - munkaerő esetén a vállalat nagyrészt megtakaríthatja a képzés, az adminisztráció, valamint a válogatás költségeit. Ezek tetemes részét a munkaerő-kölcsönző vagy szerződéses beszállító cég (outsourcer) állja, és csak igen kis részben hárul az ideiglenes megoldásokat választó vállalatra. Az ideiglenes foglalkoztatás legfő́bb motivációi az alábbiak:

1. Gyors és viszonylag kis költségekkel járó alkalmazkodás a piaci bizonytalanságokhoz, a munkaerő leépítésével kapcsolatos nehézségek és költségek elkerülése.

2. A munkavállalóval kapcsolatos bizonytalanságok (betegség, családi körülmények megváltozása stb.) gyors áthidalása viszonylag kis költségekkel.

3. A munkaerő minôségével kapcsolatos aszimmetrikus információkból adódó hibás döntések elkerïlése, illetve az ezzel kapcsolatos nehézségek és költségek csökkentése.

1. A feltételes foglalkoztatás legfóbb haszna a munkáltatók szempontjából a piaci bizonytalanságokhoz való gyors alkalmazkodás lehetősége. A feltételesen foglalkoztatottak (benne a kölcsön-munkaerők) háromféleképpen is növelik a foglalkoztatás rugalmasságát:

- Lehetôvé teszik az időbeli rugalmasságot, azaz alkalmazkodnak a vállalati munkaeróigények napi, szezonális és ciklikus ingadozásaihoz.

- Előmozdítják a funkcionális rugalmasságot, vagyis módot adnak klienseiknek arra, hogy bizonyos képességeket és speciális szaktudást szelektív és nem folytonos jelleggel vegyenek igénybe...

- és a szabályozással ${ }^{3}$ összefüggố rugalmasságot, amely lehetôséget teremt arra, hogy a munkájukat igénybe vevôk megfeleljenek a kor parancsának: azaz a hagyományos munkaviszony liberalizálásának, deinstitucionalizálásának és deregulásának. (Theodore \& Peck, 2002:469)

A mai világban a cégek korántsem mozognak olyan biztos talajon beruházási döntéseikben, mint 30 vagy 50 évvel ezelótt. A kalkulációkban - legyen szó akár zöldmezős, akár bővítő beruházásról - minden eshetôséggel számolniuk kell. A leggondosabban megtervezett akciónak is legalább három lehetséges kimenetele van: a) lényegesen jobban „bejön” a beruházás, mint amire számítottak; b) csalódást okoz, és gyorsan le kell állítani; c) továbbra is fennmarad a bizonytalanság, és nem lehet tudni, hogy alakulnak dolgok a jövóben. A cég mindhárom opcióra megfeleló választ tud adni, ha a beruházás üzembe helyezésekor ideiglenes foglalkoztatottakkal tölti fel a stábot:

a) átlag feletti eredményesség mellett radikálisan csökken a bizonytalansági tényezố, és a cég felcserélheti az átmeneti munkaerốt állandó dolgozókkal; 
b) nem kielégítő eredmények esetén a cég alacsony költséggel elbocsáthatja ideiglenes dolgozóit, és kiveheti pénzét az elfuserált üzletből;

c) ha a helyzet továbbra is bizonytalan marad, a cég fenntarthatja a stáb feltételes foglalkoztatását, és késlelteti az ideiglenes dolgozók állandósítását (Foote \& Folta, 2003).

Vegyük észre, hogy a termelố vállalat a tốzsdei aktorokhoz hasonlóan játszik a foglalkoztatással. Akár így, akár úgy alakul a helyzet, akár „bika” a szóban forgó beruházás, akár „medve”, a cég mindenképpen jól jár az ideiglenes dolgozókkal. Ha másért nem, akkor azért, mert megmenekül az effajta foglalkoztatással a nagyobb veszteségektôl.

2. Az információtechnológiák, az ezeken nyugvó komplex vállalati rendszerek múködtetésének biztonsága nem múlhat azon, hogy egy-egy kulcsember ágynak dôl, vagy családi problémái miatt téves döntéseket hoz. Ezt a kockázatot nem viseli el manapság már a vállalat, az ehhez hasonló problémákat inkább ideiglenes dolgozókkal oldja meg.

3. Az ideiglenes foglalkoztatás nemcsak a rugalmasságot és alkalmazkodóképességet növeli, hanem kitünő sæelekciós lehetőség is, ami a diploma minősítésénél vagy a fejvadászok által rendszeresített pszichológiai teszteknél jóval megbízhatóbb, kivételesen magas érvényességgel. A munkaviszonyt övezô bizonytalanság ugyanis egyáltalán nem csak piac kiszámíthatatlanságára vezethető vissza. A bizonytalanság jelentôs forrása maga a munkavállaló. A tudás alapú termelési folyamatban korántsem mellékes a reménybeli dolgozók képessége. Akad olyan munkát keresô, aki kiváló képességú, de olyan is, aki ugyanolyan diplomával alul teljesít. A munkaadó nem igazán tudja elsőre megállapítani kiben, mi lakozik. „Ha bizonytalanság van a jelöltek kvalifikációja körül, aะ állandó munkaerố alkalmazásának halas»tása hasะnos lehet. Ilyenkor ideiglenesként veszik fel őket, de állandónak szánt munkakörökbe azzal a céllal, hogy később állandósíthatják óket." (Foote \& Folta, 2003)

A feltételes foglalkoztatásnak megvannak persze a maga negatívumai is. A negatívumok elsôsorban a munkavállaló oldalán érzékelhetôk.

- A feltételesen foglalkoztatott dolgozók kevesebbet kerestek, mint azok, akik teljes állással rendelkeznek.

- Az esetek többségében nem élvezhetik a munkáltató által biztosított egészségügyi és nyugdíjazási programok elônyeit. (Harrison, 1997:38-45).

Mindazonáltal, ha a béreket és az alkalmazotti kedvezményeket a feltételes (alkalmi) és a nem feltételes (teljes) foglalkoztatási formákkal összehasonlítjuk, akkor nagyon sokféle változatot találunk. A változatok a kor, a képzettségi szint, a foglalkozási terület és az iparág szerint különböztethetôk meg. Az ideiglenes foglalkoztatás egyáltalán nem mindig jelent hátrányt a béreket, jövedelmeket illetôen sem. Profeszszionális szakértôi munkák esetén éppen az ideiglenes megbízás jár nagyobb bérrel. Míg egyszerúbb irodai munkáknál a feltételesen foglalkoztatottak hátrányban vannak, különösen, ami a vállalati juttatásokat, kedvezményeket illeti. 
- Akármennyit is dolgoznak a feltételes munkások, a cég számára, mindig külsők maradnak (Foote \& Folta, 2003).

- A feltételes foglalkoztatottak jelenléte nagyobb áldozatokra készteti az állandó foglalkoztatottakat, s mivel féltik stabil munkahelyüket, szinte bármit megtesznek érte.

1976 és 1993 között 27 százalékkal nőtt azoknak a kanadaiaknak a száma, akik hetente több mint 50 órát dolgoztak. És a legtöbbjük esetében kilátás sincs arra, hogy ez mérséklődjön. „Az emberek úgy érzik, hogy ha nem dolgoznak keményen, akkor minden széthullik. Ezek az emberek taposómalomban élnek." (Idézi: Schachter (Schachter, 1996:86))

- a munkához való egyre szenvedélyesebb ragaszkodás - nem kis részben a feltételes foglalkoztatás terjedésének köszönhetően - olyan méreteket öltött, amit azzal lehetne jellemezni, hogy számos ember számára a munka önértékké válik.

A feltételesen foglalkoztatottaknak a munkáltatók szemszögéböl nézve is vannak negatívumai:

- A feltételesen foglalkoztatott dolgozók jelenléte az állandó munkavállalók között negatívan hat az utóbbiak céghúségére,

- Az ideiglenes foglalkoztatás gyakorta alacsonyabb termelékenységhez is vezet.

- Paradox hatásként az atipikus foglalkoztatási viszonyok bővülésével a vállalati hatalmi viszonyok és fegyelmezési eszközök is fellazulnak, annak ellenére, hogy e foglalkoztatási formákban a teljesítménykényszer erôsebb, mint a hagyományos formáknál.

Ha az egész társadalomra gyakorolt hatást tekintjük, a negatívumok még erősebben kiütköznek:

- A munkaviszonyok fellazításával a bérmunka által közvetített társadalmi öszszetartozás érzése fellazul.

- A relatíve biztos és privilegizált foglalkoztatottak és a marginális szektorokban dolgozók közötti megosztottság erôsödésével egyfajta „szociális apartheid” alakult ki, amely hosszabb távon fenyegetést jelenthet a fennálló gazdasági berendezkedésre.

- Akárcsak a távmunka, (a vele gyakran összekapcsolódó) feltételes munka is több terhet hárít a társadalomra, illetve az állami büdzsére, mint a hagyományos foglalkoztatás, amelyben széleskörúek a vállalati juttatások is.

Az ideiglenes munkaerố alkalmazását befolyásoló tényezók: minél stabilabb, annál labilisabb

Az ideiglenes munkaerô alkalmazása egyenetlenül növekszik mind a fejlett világban, mind globálisan. Általánosságban elmondható, hogy minél nagyobb a bizonytalanság, annál nagyobb az ideiglenes munkaerő használatára vonatkozó opcióérték, 
és annál valószínúbb, hogy a cégek alkalmazni fogják a feltételes foglalkoztatást stábjuk feltöltésére. A munkaerôpiac regulálása ilyen körülmények között szükségképpen paradox hatású. Minél jobban szabályozott a munkapiac, minél több paragrafussal bástyázza körül egy-egy ország az állandó foglalkoztatást, annál nagyobb a vállalatok sæámára a: ideiglenes munkaeró csábitása, és annál valószínúbb, hogy a cégek feltételesen foglalkoztatottakat alkalmaznak stábjuk feltöltésére.

Ugyanebben az irányban hat az is, hogy a munkáltatók vonakodnak negatív értékelést kiadni az állandó dolgozókról, és ez még tovább növeli az állandó dolgozók felvételének kockázatát. Ugyancsak az ideiglenes foglalkoztatást segítô tényezőnek számít az állandó foglalkoztatottak magas bére. Úgyis fogalmazhatunk, hogy minél stabilabb az állandó foglalkoztatottak helyzete, annál labilisabb, mert annál nagyobb az ösztönzés az ideiglenes foglalkoztatásra, és annál nehezebben szánják rá a vállalatok magukat ara, hogy állandó állásokat nyissanak meg, vagy állandósítsák ideiglenesen foglalkoztatott alkalmazottaikat. (Foote \& Folta, 2003)

\section{A szakmai dimenzió újraértelmezése: a verzatil munkavállalók}

A bizonytalanság, amely a vállalatokat a munkaviszony fellazítására, az ideiglenes alkalmazás kiszélesítésére sarkallja, a munkavállalókat kínálatuk kiszélesitésére, diverzifikálására ösatökéli. Nemcsak az bizonytalan ugyanis, hogy hol, és milyen jellegú - állandó vagy átmeneti - munkához juthatnak, hanem az is, hogy milyen munkához. A helyzetre való adekvát válasz, hogy - bizonyos korlátok között - bármilyen munkát elvállalnak. A munkavállalók mind nagyobb részének kell követnie a Nissan cég jelmondatában foglalt maximát: Bárkinek, bármikor, bárhol, bármit! A munkavállalók többsége nem ragaszkodhat eredeti szakmájához, kínálatát jelentôsen ki kell bôvítenie.

Az információtechnológiák elterjedésével tehát a nemcsak a termékek és a termelési folyamatok válnak a legfóbb termelőeszközhöz: a számítógépekhez hasonlóan variábilissá, rugalmasan alakíthatóvá, hanem a termékeket létrehozó ember maga is. Nemcsak a cég állít össze változó számú és képzettségú munkásokból álló teameket a változó piaci helyzetnek megfelelően, hanem a munkások, az alkalmazottak mint egyének is modulárisak. A kor kihívásaihoz alkalmazkodó foglalkoztatottak több vasat tartanak a túzben, s e vasakat a munkapiaci helyzet ingadozásainak megfelelően cserélgetik. Egyetlen kiragadott individuum munkaereje önmagában véve sem homogén manapság, képzettsége, képességei modulokból állnak össze. A több lábon állás az egyetlen biztosíték számára, hogy minden piacon értékesíthetố (vagy fogalmazzunk szerényebben: több piacon értékesíthető) szakértelmet kínálhasson, s a képességek portfóliójából mindig azt vegye elő, amire valahol éppen kereslet támad.

A „verzatil”, saját tudástőkéjét egyfajta befektetési portfólióként folyamatosan változtatható munkavállaló új módon veti fel a hozzáértés, a kompetencia problémáját, amely ma - talán nem véletlenül - a vállalatelmélet ${ }^{14}$ központi kategóriája. A munkaerő rugalmassága csak kompetenciái portfóliójának kialakításával, illetve folyamatos átrendezésével lehetséges. 
„Különösen az utóbbi húsz évben, a munkaidő-megtakarító eszközök fejlődésével radikálisan megváltoztak a munkakörülmények és a munka világa. A munka világának jellege és viszonyai eltávolodtak az egyféle munkaterületre felépített karrier sztereotípiájától (single-career work life), és elôtérbe kerültek a dolgozói lét többféle irányba vezető útjai (multiple workpaths)" (Rawolle, 2000:16). A rugalmas foglalkoztatási viszonyok gyorsan alkalmazkodó, verzatil munkaerôt követelnek, sokféle kompetenciával. Vége az egyenes vonalú karriereknek, senki sem készíthet hosszú távú karrierterveket, s a portfólió- élet válik jellemzôvé (Broadfoot, 1998:451). A portfólió-élet megvalósításának elemi előfeltétele egy olyan oktatási és szakképzési rendszer, amely technológiai orientációját tekintve a sokoldalúság kialakítására helyezi a hangsúlyt. Ezért aztán egyáltalán nem meglepố, hogy jelentôs változásokat tapasztalhatunk a korábbiakhoz képest a munkavállalók képzettségében, illetve képzésében is.

Az iskolában megszerezett tudás gyakran az iskola befejezése után két-három évvel már elavultnak számít. A tanulás és a munka fázisa többé nem különíthetô el egymástól (lifelong learning). A munka tartalma igen nagy részben tanulás, a munka és a tanulás között határozott konvergencia tapasztalható (learning by doing). (Tapscott, 1996) ${ }^{15} \mathrm{Az}$ élethossziglani tanulás vagy hipertanulás (Matanovich \& Cressman, 1996) nemcsak a laza és állandóan változó foglalkoztatási viszonyok következménye és sajátja, ez a helyben maradó munkaerőre is vonatkozik. A rugalmas foglalkoztatási viszonyokból, a gyakori munkahely- és szakmaváltásból következik az állandó tanulás, amely pedig rugalmassá teszi a dolgozókat, és megkönnyíti számukra a szakma- és munkahelyváltást. Egymást erősítő folyamatokról, illetve jelenségekrôl van tehát szó. A „nomadizálás” elősegíti a tanulást, míg a helyhez kötöttség korlátozza a tapasztalatszerzési lehetôségeket. Az egy-egy projektre szerződtetett vagy munkaerő-kölcsönző cégtől kölcsönzött munkavállalók kalandozásaik közben szinte a „csizmáikon viszik át” a tudást az egyik projektból a másikhoz, az egyik szervezetból a másikba. A termelésben foglalt tanulás nem egyszerúen kísérôjelensége a folyamatnak, hanem a lényege.

A foglalkoztatottaknak - tetszik, nem tetszik - igazodniuk kell a termelés általános irányzataihoz: ha a termelés globalizálódik, az alkalmazott munkaerônek is „határok nélkül foglalkoztathatóvá” kell lennie. Ha a termelés rugalmas, akkor a munkaviszonyok sem rögzíthetôk évekre, még kevésbé évtizedekre. Ha a termelés variábilis, modulszerû, a munkaerônek is modulárissá kell válnia, s - portfóliójában többféle kompetenciával - ugrásra készen kell várnia a legkülönfélébb típusú foglalkoztatásra.

A munka és a többi termelési tényezô együttmozgása, fejlődésük párhuzamossága persze a legkevésbé sem új, csak új formában jelentkezik. Hisz az ipari forradalom hajnalán, amikor a tőke koncentrálódása révén létrejött a gyárrendszer, a munkaerőnek is koncentrálódnia kellett. Amikor a tôke egyszerú mozzanatokra bontva, standardizálta és futószalagra szervezte a termelést, a munkaerô is standardizálódott. Amikor a monumentális gyáróriásokban a tôkespecifikusság magas foka, azaz a kizáró- 
lag egy meghatározott termelési folyamatra alkalmazható célberendezések voltak jellemzők, akkor a munkaerő esetében is felértékelődött az elkötelezettség, és az egyegy specifikus folyamatban hosszú évek alatt megszerezhető gyakorlat miatt, a munkaerố is többé-kevésbé „,bebetonozottá” vált. Az új tehát nem az alapvetô technológiai-termelési irányzatok és a munka világában tapasztalható trendek szoros logikai kapcsolata, hanem azok a fejlemények, amelyek a 20. és a 21. század fordulóján e szoros logikai kapcsolat talaján a foglalkoztatásban létrejöttek.

\section{JEGYZETEK}

A cikk hátteréül szolgáló kutatások az „Információgazdaság és identitás” nevű tudományos iskolában, az OTKA támogatásával, a TS 40768 sz. OTKA-szerződés keretében folynak.

2 Az idézett részt meglehetôsen szabadon fordítottam, ezért megadom a szó szerinti angol szöveget is: „Drop by the Manila offices of Source 1 Asia at two or three in the morning, and you might think you've stumbled into some late-night college cram session. Some 750 men and women in their early 20 s, jazzed on cappuccino and junk food, are pulling all-nighters in front of their computers. The walls of the cavernous room are painted hot pink, purple, and lime green. But it's not Calculus 101 that has these Filipinos burning the midnight oil. They're busy handling credit-card queries from Chevron Texaco Corp. (CVX) customers and walking users through the intricacies of Microsoft Corp. Software. (Balfour, 2003:1)

3 Információtechnológián egyezményesen a gépalapú technológiát értik, amely aktív információkezelést és - feldolgozást is jelent. Felöleli a szoftverrendszereket, a nem gépi információs forrásokat is. A kettőt együtt, mint ipart az ENSZ Gazdasági Bizottságának öt alágazatot felölelő definíciója rögzíti: 1 . félvezetôipar, 2. számítógépipar, 3, szoftveripar, 4. távközlési berendezések ipara, 5. távközlési szolgáltatások.

4 Ha figyelembe veszzük, hogy az Internetet csak a 90-es évek elején kezdték szélesebb körben alkalmazni, a globális iroda céljaira való kiaknázása gyakorlatilag idôeltolódás nélkül, azonnal megkezdődött.

${ }^{5}$ Az ipari távmunka a Magyarországon bedolgozás néven ismert formához hasonlít leginkább.

${ }^{6}$ A telemenedzserek néhány kollégájukat irányító szakértők vagy szervezéssel foglalkozó munkatársak. Ezekre itt külön nem térünk ki.

7 Ránézésre ugyan egy olajmezô ma sem nagyon hasonlít a Szilícium-völgyre, de ez csak a látszat! Ebben az iparban ma már a lényeg a 3D (háromdimenziós) szeizmikus képalkotó szoftver, amellyel az olaj helye a föld alatt vagy a tenger mélyén behatárolható. A kitermelés hatékonysága nagyjából ezeknek a képalkotó szoftvereknek a hatékonyságán múlik.

${ }^{8}$ Emlékeztetni szeretnénk arra, hogy 1820-ban az ipari forradalom kellős közepén még NagyBritanniában is kivételt képeztek a gyári munkások, és senki sem láthatta elôre, hogy egy évszázaddal késóbb milyen nagy horderejú változások mennek majd végbe. Az ipari társadalomra jellemző gyári munka csak 1914-re teljesedett ki (Mokyr, 2001:10).

9 Work anywhere, anytime is the new paradigm. Your car, your home, your office, even your client's office. Work alone, coupled, teamed. Work in real space or in cyberspace. It amounts to a massive disaggregation of work, spinning outside the walls and confines of the traditional office. (My Workplace, 2003:1) 
${ }^{10}$ A moduláris, testre szabott termelésrôl részletesen lásd Szabó - Kocsis(Szabó \& Kocsis, 2002)

${ }^{11}$ Magyarul inkább „atipikus foglalkoztatottaknak” nevezik a munkaerô-állomány eme gyorsan növekvő részét (Laky, 1998).

${ }^{12}$ A válság a 70-es években arra vezethető vissza, hogy ez a produkciós és reprodukciós modell immanens korlátokba ütközött. Ez nemcsak az erőforrás pazarlással és a környezetszennyezéssel volt kapcsolatban, hanem a fordizmusra jellemző foglalkoztatási viszonyokkal is. A fordista, erôs szakszervezetekre és állami közvetítésre támaszkodó kompromisszum a munkáltatók és a munkavállalók között olyan speciális intézményekben öltött testet, mint a munkáltatói egyeztető tanács vagy az állami társadalombiztosítási rendszer.

${ }^{13}$ Magyarországon ezt nagyon is jól ismerjük a múltból, amikor a különféle tsz-melléküzemágak a nagyvállalatoknak kölcsönöztek ki egész brigádokat, hogy ily módon kerülhessék ki a nagyvállalatokra vonatkozó merev munkaügyi és bérszabályozást.

${ }^{14}$ Pontosabban az ún. erőforrás alapú vállalatelméletek alapvetô terminusa a kompetencia. Részletesen lásd errốl Kocsis-Szabó (Kocsis \& Szabó, 2000) 3. fejezetét.

${ }^{15}$ V.ö. Matanovich - Cressman (Matanovich \& Cressman, 1996)

\section{IRODALOM}

Back (2001): Back office to the world. Economist, Vol. 360. No. 8220. May 5-11 pp. 59-61. (Szerző nélkül)

Balfour F. (2003): The Way, Way Back Office. BusinessWeek Online, February 3, http://www.businessweek.com/magazine/content/03_05/b3818011.htm

Bertin, I. \& O'Neill, G. (1996): Telefutures. Forbairt and Telecom Eireann, Dublin http://www.forbairt.ie/telefutures).

Broadfoot, P. (1998): Records of Achievement and the Learning Society: A Tale of Two Discourses. Assessment in Education: Principles, Policy \& Practice, Vol. 5. No. 3,. November, pp. 447-478.

Cappelli, P. \& Bassi, L. \& Katz, H. \& Knoke, D. \& Osterman, P. \& Useem, M. (1997): Change at Work. University Press, New - York - Oxford.

Delphi Brings (2000): Delphi Brings the Latest in High-Tech Electronics to Automotive Market. 2000. október 31.

http://www.delphi-pss.com/na_eng/press.asp?articleid=5996

Foote, D. A. \& Folta, T. B (2003): Temporary workers as real option. Human Resource Management Review, Article in Press, Uncorrected Proof.

Graham, L.(1995): On the Line at Subaru-Isuzu. The Japanese Model and the American Worker. Cornell University Press, Ithaca, NY.

Harrison, B. (1997): The dark side of flexible production. Technology Review, Vol. 97. No. 4. May-June, pp. 38-45.

Hipple, S. (2001): Contingent work in the late-1990s. Monthly Labor Review, Vol. 124. No. 3. March, pp. 3-27.

Kocsis Éva \& Szabó Katalin (2000): A posztmodern vállalat. Tanulás és hálózatosodás az új gazdaságban. Oktatási Minisztérium, Budapest.

Laky Teréz (1998): Változó fogalmak a munka változó világában. Közgazdasági Szemle, 2. sz. pp. 123-137.

Lynn, G: The future of contingent work. Personnel Journal, Vol. 74. No 4. April 1. p. 54. 
Matanovich, T. J. \& Cressman, G. E. (1996): Hyper-Learning in a Hyper-World. Marketing Management, Vol. 5. Issue 2. Summer. pp. 42-54.

Mokyr, J. (2001): Economic History and the „New Economy”. Business Economics, Vol.36. No. 2. April, pp. 9-14.

MY WORKPLACE (2003): My Workplace... work anywhere anytime. Az NSV Department of Commerce homepage-dzse, United Kingdom, London. http://www.dir.nsw.gov.au/workplace/manage/workanywhere.html.

O'c. Hamilton, J. \& Baker, S. (1997): The new workplace. Walls are falling as the "'office of the future" finally takes shape. Business Week Online, June 14, http://www. businessweek.com/1996/18/b34731.htm

Petersen, J. L.(1997): The „Wild Cards” in Our Future: Preparing for the Improbable. Futurist, Vol. 31. Issue 4, July/August, pp. 43-48.

Pine II., B. J. \& Victor, B. \& Boynton, A. C. (1993): Making mass customization work. Harvard Business Review, Vol. 71. No.5. pp. 108-117.

Rademacher, F. J.(2003): Zukunft der Arbeit. info@faw.uni-ulm.de

Rauch, J. (2001): The New Old Economy: Oil, Computers, and the Reinvention of the Earth. Atlantic Monthly, Vol. 287. No. 1. pp. 35-49.

Rawolle, S. (2000): Work and the Knowledge Economy. Social Alternatives, Vol.19. No. 4. October, pp. 14-18.

Saveri, A. (1995): Unbundling labor in the 21st century. Worldwide Salary and Opinion Survey) Electronic Engineering Times, No. 859. July 31. pp. 94-99.

Scheier, R. L. (1995): Universal code. (US firms save costs by tapping programming talent overseas) (PC Week Executive) PC Week, April 3, Vol.12 No.13 pp. E1-E3,

Segal, Lewis M. (1996): Flexible employment: Composition and trends. Journal of Labor Research, Vol.17. No.4. Autumn. pp. 525-542.

Schachter, Harvey (1996): Slaves of the new economy. Canadian Business, Vol. 69. No. 4. pp. 86-92.

Smith, W: (1994): Institutionalizing Flexibility in a Service Firm. Multiple Contingencies and Hidden Hierarchies. Work and Occupations, Vol. 21. pp. 287-304.

Szabó Katalin (1995): Drótmenedzsment, avagy a káosz irányítása. Társadalmi Szemle, 50. évf. 7. sz. 19-28. p.

Szabó Katalin \& Kocsis Éva (2002): Digitális paradicsom vagy falanszter. A személyes tömegtermelés. Aula, Budapest. 233. p.

Tapscott, D.(1996): The Digital Economy: Promise and Peril in the Age of Networked Intelligence. Educom Review, Vol. 31. Issue 3. May/June. pp. 52-57.

TELEWORKING... (2003): Teleworking Ireland http//:wwwtelework.ie /newsite/ FAQS/ FAQs.html

TELEWORKING AND RURAL... (1996): Teleworking and Rural Developmen. comission Salisbury.

THE CHINA SYNDROME...(1996): The China Syndrome. New technology is exposing more workers to international competition. Economist, szeptember 28. Vol. 340. Issue 7985. Supplement, pp. 31-33.

Theodore, N. \& Peck, J (2002):The temporary staffing industry: growth imperatives and limits to contingency Economic Geography, Vol.78. Issue 4. October, pp. 463-493. 
Thomas, R. J. (1994): What Machines Can't Do: Politics and Technology in the Industrial Enterprise. University of California Press, Berkeley.

Uzzi, B. \& Barshness, Z. (1998): Contingent Employment in British Establishments:

Organizational Determinats of the Use of Fixed Term Hires and part-Time

Workeres. Social Forces, Vol 66, Issue 3. March,

Wiens-Tuers, B. A. (2001): Employee Attachment and Temporary Workers. Journal of Economic Issues, Vol.35. No.1. pp. 45-60. 